\title{
Liberia's Run-up to 2017: Continuity and Change in a Long History of Electoral Politics
}

If successfully orchestrated, the October 2017 elections in Liberia will mark the first time in recent memory when a democratically elected Liberian president - Ellen Johnson Sirleaf - will hand over power to a similarly elected head of state. This will most likely be a close election and the briefing investigates changes and continuities in the candidates, political parties, electoral processes and the workings of the state of Liberia at a watershed moment in a long and shifting democratic history.

\section{Keywords}

Liberia, elections, post-war development, transnationalism, Ellen Johnson Sirleaf, George Weah

\section{Introduction}

In a striking paradox, dramatic changes in the character of Liberian elections have occurred across space and time, especially since the end of armed conflict in 2003, whilst many difficulties remain ahead of hotly contested forthcoming elections. Likely to be very close, Liberia's third, post-war elections slated for October 2017 already indicate continuities and changes from the immediate electoral past, and indeed from the pre-war and wartime polls. These elections, if successfully orchestrated, will mark the first time in recent memory where a democratically elected Liberian president will hand over power to a similarly elected head of state.

The aim of this briefing is to consider the candidates, parties, processes and the state of Liberia in advance of voting in October and to map where continuities and changes may lie. For example, President Ellen Johnson Sirleaf is stepping down leaving a rather unpredictable field with some familiar names-including Sirleaf's Vice President Joseph Boakai ${ }^{i}$ of the ruling Unity Party (UP) and former footballer and 2005 presidential candidate George Weah of the Congress for Democratic Change (CDC) amongst the opposition-several relative newcomers and no women as viable presidential frontrunners. Beginning with a historical mapping of Liberia's democratic trajectory, the briefing speaks to the notion of what constitutes electoral democracy, the associated fields of state-society relations, identity, multi-party elections and transnationalism, and concludes by taking stock of electoral politics at this juncture in Liberia.

For over a century, from 1878 until 1980, Liberia's democracy was so restricted that Africa's first republic effectively gave birth to Africa's first one-party state. The True Whig Party (TWP), dominated by black settlers, ruled through an electoral system which rarely saw any potential for a turnover and where the party elite monopolised the political and economic environment (Liebenow 1987). Liberia had just two presidents between the end of World War II and the start of the 1980s (Ibid). TWP hegemony, however, came to an abrupt end in the military coup of 1980 which brought the junior army officer, Samuel Kanyon Doe, to power (Ibid). In electoral terms, Doe's tenure was accompanied by 
greater levels of violence and rigging when he was forced to the ballot box in 1985 by internal pressure and external persuasion from Liberia's main supporter, the United States (Sawyer 2005; Sirleaf 2010; Berkeley 1986). Most estimates put Doe's presidential vote in 1985 at about half of the $51 \%$ that he claimed (Ibid). Following the election, Liberia slid towards greater uncertainty and finally war in December 1989. After nearly seven years of harrowing armed conflict, a peace deal in 1996 led to elections the following year. Although rebel leader Charles Taylor was always the likely winner due to the twin fears of his return to armed conflict if he lost and the probability that none of the other candidates would be able to maintain peace, the 1997 polls were mostly seen as another in the Liberian canon of questionable democratic elections (Sawyer 2005; Harris 1999; Lyons 1999).

Much of this, however, changed dramatically from 2005 onwards. The second outbreak of Liberia's conflict was brought to an end by the exile of Taylor in 2003 and power passed to the National Transitional Government of Liberia (NTGL). The ensuing polls were extraordinary in many ways. In a complete shift from the past, 2005 was marked by highly competitive elections with no incumbent and the use of state resources seemingly spread across a number of parties with access to the coalition NTGL. Violence, overt rigging and indeed rebel parties were almost absent, the latter probably content with the victory against Taylor or the spoils of the coalition government. The results were also remarkable (Harris 2006; Sawyer 2008). Sirleaf came out as a clear winner against Weah in the presidential run-off after only coming second in the first poll. Sirleaf's UP was not even the largest party in either the Senate or the House of Representatives, with Weah's CDC winning almost double the number of UP seats in the House (NEC Liberia 2005). Candidates from a plethora of parties and independents gained unlikely victories all over the country (Ibid). There were no clean sweeps of presidential, Senate and House elections by any party in any of Liberia's sub-political divisions - called countiesshowing that party loyalty was far from guaranteed (Ibid). There were still the problems of money and where it comes from and goes to, and perhaps an understandably large post-war presence of diaspora returnees, but the dispersal of party representation in a relatively clean and peaceful election was not only unusual in Liberia but equally so in Africa.

The issue of incumbency re-emerged for the 2011 elections with Sirleaf standing for president once again as standard bearer of the UP (Harris and Lewis 2012). As might be expected after a term where peace had held and some economic progress made and with incumbent advantage, Sirleaf won the presidential election and the UP increased its total of Representatives threefold and more than doubled its number of Senators (NEC Liberia 2011). However, Sirleaf once again only secured victory in the presidential run-off which was this time boycotted by CDC, and the UP's gains still left them significantly short of a majority in either legislative body (Ibid). Representation from small parties and independents remained high (Ibid). Regional blocs became clearer in 2011, but they were still permeated by other parties and independents, showing again that party consolidation remains problematic (Ibid). However, pockets of violence returned and the run-off boycott was inspired by allegations of electoral fraud (Harris and Lewis 2012). As in 
2005, diaspora returnees and transnationals played a large role, including the opposition ticket of Winston Tubman and Weah for president and vice-president, respectively.

\section{Continuities}

From a perspective of continuity, one might then record elements that have endured in the condition of the state and the country, the candidates and parties, and the electoral processes. A 2016 Afrobarometer survey noted that around half of Liberians surveyed said Liberia was enjoying a 'full democracy' or a 'democracy with minor problems' with the other half much less optimistic (Okuru and Armah-Attoh 2016). This needs some explanation.

First, then, one might observe longstanding patterns of state activity and strained statesociety relations that are more or less maintained. Although the state and infrastructure function better than at any point since the 1970s, it is still operating at a low capacity, particularly as it relates to economic revitalisation. Sirleaf's first term was marked by steady growth rates of between $5 \%$ and $8 \%$, foreign direct investment totalling US\$16 billion, and sharp increases in export revenue, yet these macro-level advancements did not significantly alter the living conditions of most Liberians, $64 \%$ of whom still live below the poverty line (Pailey 2014). Similarly, gross economic mismanagement led to repeated budget shortfalls in the early part of Sirleaf's second term followed by high inflation, despite her administration receiving donor largess in the millions (Ibid). The Ebola epidemic of 2014/2015 and recent downturn in iron ore and rubber prices have spiralled Liberia into a further recession, with recent protests against exchange rate fluctuation and the government's decision to increase taxes on basic commodities and telecommunications foregrounding the economy as a hot-button topic for elections in 2017 and beyond (AfDB 2016; Daily Observer 2017b; Front Page Africa 2017; Bush Chicken 2017a).

Equally, the twin imperatives of diverting state resources for personal gain and political and social support, importantly at election times, are regularly contested as well as covered in media reports on, and even state narratives of, corruption. One need not look far to find stories of corruption involving elected and appointed officials such as the 2016 state investigation of UK company, Sable Mining, and its alleged attempts to secure a major iron ore concession in northern Liberia by hiring in 2010 top Liberian lawyer Varney Sherman, now UP chair and Grand Cape Mount Senator, to bribe, amongst others, then Speaker of the House, J. Alex Tyler and Sirleaf's son, Fumba Sirleaf (Global Witness 2016). The president has been criticised from many quarters for the promotion of her relatives to high positions of government (BBC 2012) and John Morlu's strident claims as Auditor General about corruption in the Sirleaf administration, captured further below, are an indication that elected and appointed positions are often perceived as the gateway for amassing personal wealth that could be used for campaigning during elections.

As in most elections, African and otherwise, being the incumbent party will once again allow the ruling UP, now fronted by vice-president Boakai, to take a considerable 
advantage. On the one hand, for example, state funds can be diverted into infrastructure projects in politically sensitive areas. On the other, funds can be channelled into campaigning, either in the form of razzmatazz - in which major streets are blocked for hours with long convoys of campaign cars - the distribution of t-shirts and bags of rice or in terms of keeping sweet those in positions of government, state, community or 'traditional' authority who can, or say they can, deliver bloc votes. Boakai is surely aware of democratic history in Africa, where turnovers are more common and ruling parties are more vulnerable when the incumbent stands down and a successor is fronted (Cheeseman 2010), and Sirleaf's mixed record will mean he needs to take stock accordingly.

Another method of shoring up support is to lean on ethno-regional bases. This is not so straightforward in Liberia as in other African states such as neighbouring Sierra Leone or Ghana, where patterns are more, if not completely, predictable (Conteh and Harris 2014c; Bening and Kelly 2013). Liberia's recent history of wide representation across many parties and independents and high numbers of local-level turnovers shows an electorate weighing up its options and parties that are not consolidated enough to forge or hold onto electoral bases. These patterns continued from 2005 to 2011 and into the 2014 senatorial elections and look likely to remain, particularly given the partial political vacuum at the very top. ${ }^{\text {ii }}$ No doubt Boakai will do well in his home county of Lofa and probably Sirleaf's stronghold in Bomi, but elsewhere is in the balance. Other political leaders have similar bases but uncertain prospects further afield.

It is not just Boakai who shows continuity in key actors from the past, it is also opposition leaders. Those who have already announced they will be making a bid for the presidency include Weah; two-time presidential candidate Charles Brumskine of the Liberty Party (LP) with his base in Grand Bassa County; former rebel leader and current Senator Prince Johnson of the Movement for Democracy and Reconstruction (MDR) with considerable support in Nimba County; Morlu of the Justice and AntiCorruption Party (JACP); and wealthy businessman and former Taylor loyalist, Benoni Urey of the All Liberian Party (ALP), although the latter two have not run electorally for office before and will also appear later in the 'Facets of Change' section. Sherman would no doubt also have returned in some form if the Sable Mining affair had not emerged, and of course may still do. Although one opposition coalition appears to be sealed involving Weah, Tyler and Jewel Howard Taylor, Bong County Senator, former wife of Charles Taylor and leader of his old party, the National Patriotic Party (NPP), it is likely that most opposition political parties will return amongst numerous newer and smaller outfits. Indeed, the transnational nature of the candidates also continues, with many spending considerable time outside Liberia.

A notable omission so far has been discussion of party platforms, campaign promises and messaging, which will undoubtedly have a bearing on official campaigning from August 8 to October 8 (The New Republic 2016). As in 2005 and 2011, party policy pronouncements tend to be broad and promise the dividends of economic development such as employment and financing for agriculture; the provision of infrastructure and basic social services such as roads, electricity, education and health; the elimination of corruption; and the unity and security of the nation. Nevertheless, platforms tend not to 
differ to any great extent and actual divergences in policy are not prominent (Front Page Africa 2016k). Effectively, parties lean more on considerations of personalities, patronage, regional bases and claims to performance at national and local levels. For instance, Sirleaf made much of her international finance experience in 2005, just as some of the newer candidates profess business or banking acumen in 2017; similarly, Weah makes appeals to youth while deriving much of his support from Monrovia and the Southeast of the country.

Finally, the structures in place for the 2017 elections need some consideration. Insecurity is an ever-present, if sometimes latent, problem. The Liberian police and military have been criticised as not ready - the police struggling in particular to handle violence in Monrovia on the eve of the run-off in 2011 (Carter Center 2011) — and may face a stern test with the dwindling United Nations Mission in Liberia (UNMIL) (see 'Facets of Change' section). The latest chair of the National Elections Commission (NEC), Jerome G. Korkoya, inherits an institution which made a number of mistakes in 2011, was seen as biased by the opposition, and lost its chair before the elections took place. In 2017, the NEC continues to struggle for legitimacy with a voter registration exercise that has been mired by technical and logistical glitches from its very inception on February 1 (Daily Observer 2017a; Bush Chicken 2017b; Bush Chicken 2017c; Bush Chicken 2017d). Similar to challenges facing the NEC, constitutional and electoral laws may be brought to bear once again if events do not proceed smoothly. Previous elections have been litigious. In 2011, the Supreme Court was required to rule on the politically problematic results of the pre-election referendum, in particular deciding that the 10-year residency clause for presidential and vice-presidential candidates would only apply after 2011, and on postelection claims of electoral fraud, finding that there was insufficient evidence for the fraud alleged by the CDC (Sendolo 2011; Harris and Lewis 2012). As outlined above, 2017 promises to be a closely-fought election and hence all structures will most likely be tested.

\section{Facets of Change}

Recent changes in Liberia's political milieu will most likely have a significant bearing on election results, including the introduction of new candidates and political alliances, legal provisions and the likely consequences of the Ebola outbreak on voting patterns.

\section{New Presidential Aspirants Enter the Fray}

Previously an employee of the World Bank in Washington, DC, J. Mills Jones of the Movement for Economic Empowerment (MOVEE) party represents a prototypical returnee technocrat catapulted into Liberia's higher echelons of power with an appointment by Sirleaf as Central Bank Governor (CBL) for two consecutive terms in 2006 and 2011 (Bush Chicken 2016; Front Page Africa 2016a). Although he is largely known by Monrovia's political elite and has virtually no ethno-regional base, Jones is rumoured to have posed a threat to the House and Senate establishment because of his control over fiscal/monetary policies and financial disbursements (Front Page Africa 2015a). It is speculated that Jones' introduction of a loan programme targeting the rural 
poor was a clever guise to secure political endorsements, which prompted his resignation after the Legislature in 2014 amended sections of the Central Bank of Liberia Act prohibiting appointed officials of the Bank-including the Governor-from contesting political office 'within three years consecutively after the expiration of their tenure and in his/her resignation from the Central Bank of Liberia' (The News 2014; Government of Liberia 2014a).

Morlu, the previously mentioned firebrand anti-corruption campaigner, is widely popular for his unsubstantiated claim in 2009 that Sirleaf's government was 'three times more corrupt' than the erstwhile NTGL (VoA 2007). Employing his strong contacts in the media to publish audit reports in local dailies, Morlu earned the ire of Sirleaf for naming and shaming her loyalists for alleged financial impropriety. Needless to say, Morlu was not reappointed by Sirleaf in her second term, thus returning to the United States where he currently serves as managing partner of a Washington, DC based certified public accounting firm (Executive Mansion 2011). Although Morlu has resided consecutively in the United States since 2011 and is rumoured to hold American citizenship, he continues to elicit support from domestic citizens though his chances of winning the presidential election are slim. Like Jones, Morlu claims to represent the poor and disaffected yet his European Union-funded six-figure salary as Auditor General amidst crippling poverty in Liberia cast him primarily as an urban elite technocrat who benefitted generously from the very system he critiqued (The Perspective 2009).

Urey, the previously mentioned former head of the lucrative Bureau of Maritime Affairs (now the Liberia Maritime Authority), has never held a major elected office although he was appointed acting mayor of the city of Careysburg by Sirleaf in 2009 and subsequently elected mayor by the City Council (Executive Mansion 2009; All Liberian Party n.d.). A serial entrepreneur who reportedly amassed wealth from his dealings with Taylor, including their monopoly over the telecommunications sector via Lonestar Cell, Urey was in 2013 de-listed from a UN travel and assets freeze ban (UNSC 2013). Although the billionaire-turned-politician has the financial clout to pull off an election upset as a possible spoiler, his largely urban and peri-urban based enterprises and lack of party recognition mean he may not pose a major threat to more established figures like Boakai, Weah, Brumskine, or Johnson.

A former Executive Vice President and Chief Administrative Officer of Coca-Cola, Alexander Cummings is perhaps the greenest presidential aspirant, having held neither an elected nor an appointed position in government (Global Atlanta 2016). As a testament to his political astuteness, however, Cummings managed in April 2016 to clinch the nomination of the opposition Alternative National Congress (ANC), a splinter faction of Weah's CDC (Front Page Africa 2016c; Front Page Africa 2013). Although he has been heralded as a results-driven corporate manager, Cummings' relative inexperience in Liberia's political milieu is likely to only garner sufficient name recognition for subsequent elections should he attempt to contest in future races (Front Page Africa 2016f). Furthermore, questions about Cummings' Liberian citizenship have raised concerns about his eligibility to run (Front Page Africa 2015b). 


\section{'Pseudo-Incumbency' and Opposition Coalitions}

As a standing vice-president running for Liberia's highest office, Boakai is indicative of a 'pseudo-incumbency', which stands in stark contrast to the 'no incumbency factor' of 2005, where no presidential candidate had been elected previously, and the glaring incumbency factor of 2011, in which Sirleaf was seeking a second mandate. Boakai's unflinching loyalty and unassuming role as Sirleaf's second-in-command for 12 years have served him well, enabling him to secure the coveted UP nomination despite constant in-party bickering about succession (The News 2016).

While Boakai may be the 'pseudo-incumbent' to beat, attempts have been made by opposition parties to form a coalition that could likely oust the ruling UP. Small-scale political coalitions featured in 2011, however what remains unprecedented is the September 2016 Opposition Political Parties Collaboration Summit convened in Ganta, Nimba County, by standard bearers representing 12 leading opposition parties-including Weah and CDC, Brumskine and LP, Johnson and MDR, Urey and ALP, and Cummings and ANC (Front Page Africa 2016g). Although a possible coalition of the willing may likely upset Boakai's chances of clinching victory in a first round, it is unclear if the opposition can put away personal ambitions to effectively upend the UP by uniting behind a single candidate. As a case in point, while the Nimba meeting convened by Johnson climaxed in the endorsement of a 'Ganta Declaration', Weah subsequently forged the Coalition for Democratic Change in separate alliances with Howard Taylor's NPP and former speaker Tyler's Liberia People Democratic Party (LPDP), illustrating the potentially advantageous yet tenuous nature of opposition solidarity (Front Page Africa 2016j; Front Page Africa 2016i). The importance of an opposition coalition is not just that it unites various support bases, but also that it can help fuel a sense that the opposition might actually win thus increasing turnout in opposition areas.

\section{Enforcement of Residency, Citizenship, Code of Conduct and Campaign Finance Laws}

In 2017 , it is possible that a 10-year residency requirement for presidential candidates enshrined in the 1986 Liberian Constitution may come into effect thus barring some presidential hopefuls from entering the race (The Liberian Connection n.d.). Although the clause should have been enforced in the 2011 elections based on the outcome of a national referendum, for political expediency it was instead referred to the Supreme Court of Liberia, which maintained that it would be enforced in 2017 instead. The clause states explicitly that only those who reside in Liberia for 10 consecutive years are eligible to contest the presidency; thus, if enforced, it will likely adversely impact candidates such as Morlu and Cummings, who have not lived in the country consecutively for the past decade.

In addition to contestations over eligibility linked to residency, Liberian citizenship, or lack thereof, features more prominently in public discourse than ever before (Pailey 2014b; Pailey 2016). Akin to nearly two thirds of African countries, Liberia does not explicitly recognise dual citizenship primarily due to a contradiction between the country's 1986 Constitution — which implicitly legislates dual citizenship —and the 1973 
Aliens and Nationality Law-which explicitly renounces dual citizenship (Ibid). Although the presumed foreign citizenship of candidates such as Sirleaf and Weah have been invoked in the past two elections, current domestic and transnational debates abound about a contested dual citizenship bill introduced in 2008 (Pailey 2014b; Pailey 2016; Front Page Africa 2016b). Although the bill was rejected during the April 2015 Constitutional Review Conference held in Gbarnga, Bong County, a November 2016 vote by Liberia's House of Representatives placed the proposed bill on the table as a possible item for a forthcoming referendum (Liberia News Agency 2015; Daily Observer 2016). Given current contestations around the political subjectivity of Liberians who may have naturalised elsewhere, and thus automatically revoked their Liberian citizenship, the candidacies of Cummings, Morlu and others will likely continue to be called into question (Daily Observer 2015). This is reflective of the tactics of some incumbent governments in Africa that have used citizenship clauses and regulations to bar certain candidates from running, which has been handled relatively peacefully in some cases (ie., Zambia) while fuelling electoral violence in others (ie, Côte d'Ivoire) (Manby 2009).

As contestations over citizenship and residency continue to be more pronounced than ever before in Liberia, there have also been political fisticuffs concerning the enforceability of the 2014 Code of Conduct for civil servants, which requires presidential and legislative aspirants to resign from appointed office at least two years before elections (Front Page Africa 2016e). Although the Code of Conduct attempts to democratise the franchise, deterring candidates from exploiting public office and state funds to gain momentum, it is widely believed that it was invoked to curb the candidacies of popular political appointees, rather than intended to level the playing field.

Perhaps the most controversial law to have a major bearing on 2017 is the highly contested Democracy Sustainability Act — passed by the House and Senate in 2012 despite receiving public censure for being unwarranted in a post-war, low-income country - which allocates US\$2 million, US\$1 million, US\$500,000 per annum from the national budget to political parties, coalitions or alliances that come in first, second, and third places, respectively, in the presidential race, to be used as campaign finance in subsequent elections (Government of Liberia 2012). Given Liberia's nascent consolidation of multi-party democracy, the Act will enable parties of varying sizesalthough quite likely UP, CDC and one other - to shore up financing that would otherwise not be available, thus making 2017 high-stakes on both political and financial grounds.

\section{Missing Elements and Existential Threats}

In sharp contrast to the conspicuous presence of novice presidential hopefuls such as Cummings, Urey, Morlu and Jones, 2017 may be marked by missing elements, including Sherman, who in May 2016 was indicted alongside Tyler for allegedly violating public procurement regulations, 'committing multiple criminal offences, bribery, economic sabotage, criminal conspiracy, solicitation and facilitation' in the Sable Mining case previously mentioned (Front Page Africa 2016d). While there has been a mushrooming 
of new political parties, including Tyler's LPDP (Front Page Africa 2016h), the waning influence of Sherman and others of his ilk potentially signals major winds of change.

With Howard Taylor now definitively serving as vice-presidential running mate to Weah and Sirleaf clearly ineligible to run, 2017 also potentially signifies the first post-war election in which a woman with political clout will not be a presidential candidate ${ }^{\mathrm{iii}}$ (The New Dawn 2017; Front Page Africa 2016j). This change is indicative of a decline in the number of women in elected office under Sirleaf, which prompted the Women's Legislative Caucus to propose in 2010 a Gender Equity in Politics Act mandating that women occupy at least $30 \%$ of the leadership of political parties in Liberia (Pailey 2014a, 183-184). A diluted version of the proposed Act was incorporated into a 2014 elections law amendment that encourages political parties and coalitions to 'endeavour' to ensure that $30 \%$ or more of their governing body compositions and lists of candidates are women (Government of Liberia 2014b). Moreover, a less radical, tokenistic Affirmative Action for Equitable Participation and Representation Act of 2016 was passed reserving five seats for women in special legislative constituencies though it was immediately overturned for being 'unconstitutional' (Government of Liberia 2016; Capitol Times Online 2016; UN Women 2016; personal communication, December 12, 2016).

Other facets of change that may likely affect the outcomes of the October 2017 race are UNMIL's complete handover of responsibility for Liberia's security to the government and the aftershocks of the Ebola outbreak. While UN military presence was a consistent feature of the 2005 and 2011 elections, in 2017, UNMIL will only stand at 1,240 military personnel and 606 police officers (Executive Mansion 2016). This marginal force may or may not have an impact on the prospects of a peaceful franchise for Liberians, but it could affect the electorate's voting choices, with candidates who are likely to maintain peace faring better than those who may be more volatile, such as Johnson. Similarly, Liberians' tactile experiences of the Ebola outbreak and the government's woefully slow and inadequate response, which did not feature at all in the consciousness of voters in 2005 and 2011, will likely strengthen opposition narratives of an inefficient, Sirleaf-led administration and the inability of her 'pseudo-incumbent' vice-president to handle future outbreaks or similar existential threats (Pailey forthcoming).

\section{Conclusion}

The features of the Liberian state, political parties, candidates and electoral processes explored in this briefing illustrate that Liberia's transition into multi-party democracy and post-war transcendence will be tested in October 2017. We have opted to focus primarily on presidential prospects and party politics, which we believe will serve as a microcosm of the more expansive legislative franchise.

While the 2005 and 2011 presidential elections were saturated with recycled politicians, 2017 will usher in a new batch of candidates, some of whom are political neophytes who have been less tainted by controversy, thus possessing the name recognition and financial clout that make what appears to be predictable, unpredictable. Although political novices are least likely to win in the presidential race, they have forced established politicians 
into more meaningful political alliances and coalitions. In addition, while transnationalism remains a consistent feature of the race, with candidates residing in more than one locale vying for the highest political office, new regulations likely to be enforced around residency, citizenship, civil service comportment, and campaign finance have emerged to clip the wings of some candidates while giving others a slight advantage.

Most importantly, 2017 is largely a referendum on Sirleaf's 12-year presidency - and thus, rightly or wrongly, the position of women in elected office-as well as a litmus test for Boakai's 'pseudo-incumbency'. Although policy issues have not featured prominently in the public discourse, the electorate seems to be yearning for candidates with practical solutions to Liberia's grim socio-economic outlook. Candidates continue to preach the same gospel of economic revitalisation, reformed governance and rule of law, improved infrastructure and social services, yet, what matters most in 2017 is previous performance in actual delivery of country-wide goods, and the ability to maintain Liberia's very fragile 14-year peace. From another angle, 2017 will be a test for party consolidation, representation in the form of small parties and independents, the effects of transnationalism, ethno-regional blocs, and the perceptions of localised delivery of goods - at election time and in the last 12 years - by candidates from president through to representatives. This was all evident in the 2014 Senatorial elections where performance in more localised contexts in the previous election cycle ushered in significant losses for incumbents. The elections may also be a test for the security forces, the NEC, the courts, the new laws, and the respect that candidates, parties and supporters have for these state offices and their promulgations.

While there is a toss-up about whether continuity or change will define 2017 , we have examined in this briefing how and why it may be the most highly contested election since the country's armed conflict came to a dramatic end in 2003 and how these elections will lay down markers for future governments and voting in Liberia.

\section{References}

African Development Bank Group (AfDB). n.d. "Liberia Economic Outlook." Accessed December 11, 2016 at [http://www.afdb.org/en/countries/west-africa/liberia/liberiaeconomic-outlook/].

All Liberian Party. n.d. "Dr. Benoni Urey - the Man." Accessed November 28, 2016 at [http://www.allliberiaparty.com/political-leader/].

Bening, RB and Kelly, Bob. 2013. "The Ghanaian Elections of 2012." Review of African Political Economy 40 (137): 475-484.

Berkeley, Bill. 1986. Liberia: A Promise Betrayed. New York: Lawyers Committee for Human Rights. 
BBC. 2012. "Liberia Laureate Gbowee Chides Sirleaf on Corruption.” October 8. Accessed December 11, 2016 at [http://www.bbc.com/news/world-africa-19876111].

Bush Chicken. 2016. "Mills Jones Announces Decision to Contest for Liberia's Presidency in 2017." May 30. Accessed November 28, 2016 at [http://www.bushchicken.com/mills-jones-announces-decision-to-contest-for-liberiaspresidency-in-2017/].

Bush Chicken. 2017a. "Strike by Businesses Affecting Government Revenue Generation." February 3. Accessed February 3, 2017 at [http://www.bushchicken.com/strike-by-businesses-affecting-govt-revenue-generation/].

Bush Chicken. 2017b. "NEC Official in Upper Nimba Confirms Replacing Incompetent Voter Registration Staff." February 9. Accessed February 9, 2017 at [http://www.bushchicken.com/nec-official-in-upper-nimba-confirms-replacingincompetent-voter-registration-staff/].

Bush Chicken. 2017c. "Korkoya: NEC May Extend Voter Registration Amid Challenges." February 9. Accessed February 9, 2017 at [http://www.bushchicken.com/kokorya-nec-may-extend-voter-registration-amidchallenges/].

Bush Chicken. 2017d. "At Kendeja Voter Registration Centre, NEC Staff Issue Incomplete Voter's Card.” February 11. Accessed February 11, 2017 at [http://www.bushchicken.com/at-kendeja-voter-registration-center-nec-staff-issueincomplete-voters-card/].

Capitol Times Online. 2016. "Affirmative Action Undermines Gender Fight; Feminist Advocate Korto Williams Sounds." October 17. Accessed November 28, 2016 at [http://www.capitoltimesonline.com/index.php/news/item/1491-affirmative-actionundermines-gender-fight-feminist-advocate-korto-williams-sounds].

Carter Center. 2011. "Preliminary Statement on the Liberia Presidential Run-Off Election." November 10. Accessed December 11, 2016 at [https://www.cartercenter.org/resources/pdfs/news/peace_publications/election_reports/li beria-prelim-111011.pdf].

Cheeseman, Nic. 2010. “African Elections as Vehicles for Change." Journal of Democracy 21 (4): 139-153.

Conteh, Felix M. and David Harris. 2014. "Swings and Roundabouts: the Vagaries of Democratic Consolidation and 'Electoral Rituals' in Sierra Leone." Critical African Studies 6 (1): 57-70 
Daily Observer (Monrovia). 2015. “"I Carry an American Passport'.” December 22. Accessed November 28, 2016 at [http://allafrica.com/stories/201512220750.html].

Daily Observer (Monrovia). 2016. "7 Propositions Passed for Referendum." November 21. Accessed November 28, 2016 at [http://www.liberianobserver.com/news/7propositions-passed-referendum].

Daily Observer (Monrovia). 2017a. "Malfunctioning Cameras, Locations Stall VR Process." February 6. Accessed February 6, 2017 at [http://www.liberianobserver.com/news/malfunctioning-cameras-locations-stall-vrprocess].

Daily Observer (Monrovia). 2017b. "Over High Currency Exchange Rate: Markets, Petty Traders Ignite Protest.” January 30. Accessed January 30, 2017 at [http://www.liberianobserver.com/business/over-high-currency-exchange-rate-marketspetty-traders-ignite-protest].

Executive Mansion. 2009. "Benoni Urey Named Mayor of Careysburg." October 1. Accessed November 28, 2016 at [http://emansion.gov.lr/2press.php?news_id=1343\&related=7\&pg=sp].

Executive Mansion. 2011. “'Auditor General John Morlu Will Not Be Renominated'President Johnson Sirleaf." March 25. Accessed November 28, 2016 at [http://www.emansion.gov.lr/2press.php?news_id=1852\&related=7\&pg=sp].

Executive Mansion. 2016. "President Sirleaf Lauds UNMIL, Bilateral Partners amid Their Best Towards Liberia's Peace and Stability.” July 1. Accessed November 28, 2016 at [http://www.emansion.gov.lr/2press.php?news_id=3696\&related=7\&pg=sp].

Front Page Africa. 2013. "Liberia's Newest Political Party, Alternative National Congress of Liberia, Launces Sat." August 16. Accessed November 28, 2016 at [http://allafrica.com/stories/201308160366.html].

Front Page Africa. 2015a. "Tense Meeting-Is EJS Pressuring CBL Governor to Resign?" April 13. Accessed November 28, 2016 at [http://allafrica.com/stories/201504131125.html].

Front Page Africa. 2015b. “"I Carry an American Passport'.” December 22. Accessed November 28, 2016 at [http://allafrica.com/stories/201512220750.html].

Front Page Africa. 2016a. "Forced Exit? Liberian President Demands CBL Governor Leaves.” January 28. Accessed November 28, 2016 at [http://allafrica.com/stories/201601281350.html].

Front Page Africa. 2016b. "U.S. Citizenship Debate: ANC, CDC Tango over Weah, Cummings Nationalities." May 1. Accessed November 28, 2016 at 
[http://www.frontpageafricaonline.com/index.php/politics/696-u-s-citizenship-debateanc-cdc-tango-over-weah-cummings-nationalities].

Front Page Africa. 2016c. "Cummings Gets ANC Nomination: Promises Electricity, Better Education in Six Year." June 1. Accessed November 28, 2016 at [http://www.frontpageafricaonline.com/index.php/politics/617-cummings-gets-ancnomination-promises-electricity-better-education-in-six-year].

Front Page Africa. 2016d. "“Criminal Conspiracy': Tyler, Sherman, Others Indicted for Bribery." June 1. Accessed November 28, 2016 at [http://www.frontpageafricaonline.com/index.php/politics/894-criminal-conspiracy-tylersherman-others-indicted-for-bribery].

Front Page Africa. 2016e. "Ripple Effect of Code of Conduct Ruling on Potential Contenders." July 1. Accessed November 28, 2016 at [http://frontpageafricaonline.com/index.php/politics/1285-shattered-2017-quest-rippleeffect-of-code-of-conduct-ruling-on-potential-contenders].

Front Page Africa. 2016f. "Alex Cummings Outlines Policies for Liberia Transformation." August 1. Accessed November 28, 2016 at [http://www.frontpageafricaonline.com/index.php/politics/1744-alex-cummings-outlinespolicies-for-liberia-transformation].

Front Page Africa. 2016g. "Liberia Opposition Resolve to Collaborate for 2017 Election Victory." September 1. Accessed November 28, 2016 at [http://frontpageafricaonline.com/index.php/politics/2030-liberian-opposition-partiesgather-in-historic-city-seeking-collaboration-to-unseat-ruling-party].

Front Page Africa. 2016h. "LPDP Endorses CDC Collaboration-Elects Tyler Political Leader." November 1. Accessed November 28, 2016 at [http://allafrica.com/stories/201611020821.html].

Front Page Africa. 2016i. "Tectonic Plates of Politics: Could Liberians Be Looking Out of Box 2017?" November 19. Accessed November 28, 2016 at [http://www.frontpageafricaonline.com/index.php/politics/2597-tectonic-plates-ofpolitics-could-liberians-be-looking-out-of-box-2017].

Front Page Africa. 2016j. "Jewel Howard Taylor Leads National Patriotic Party Again." December 13. Accessed December 13, 2016 at [http://www.frontpageafricaonline.com/index.php/politics/2790-jewel-howard-taylorleads-national-patriotic-party-again?fromNewsdog=1].

Front Page Africa. 2016k. "Liberia's Election 2017: Grading Opposition Political Parties." December 20. Accessed January 6, 2017 at [http://www.frontpageafricaonline.com/index.php/politics/2843-liberia-s-election-2017grading-opposition-political-parties]. 
Front Page Africa. 2017. "Liberia: Monrovia Shuts Down-Mass Protest Over Economy Begins." January 31. Accessed January 31, 2017 at [http://allafrica.com/stories/201701310576.html].

Global Atlanta. 2016. "Former Coke Executive Vice President Joins 'Hardball' Campaign for Presidency of Liberia." September 1. Accessed November 28, 2016 at [http://www.globalatlanta.com/former-coke-executive-vice-president-joins-hardballcampaign-presidency-liberia/].

Global Witness. 2016. The Deceivers. London: Global Witness. [https://www.globalwitness.org/thedeceivers/].

Government of Liberia. 2012. An Act to Sustain Democracy through Public Funding of Political Parties, Coalitions and Alliances. Monrovia: Government of Liberia. [http://www.ilo.org/dyn/natlex/docs/ELECTRONIC/96960/114839/F970449291/LBR96960.pdf].

Government of Liberia. 2014a. An Act to Amend Part II Section (4), Subsection (1) and Part IV Section (13), Subsection (3) of an Act Authorising the Establishment of the Central Bank of Liberia (CBL) Approved March 18, 1999; and to Add Thereto Part IV Section (17) Subsection (5). Monrovia: Government of Liberia.

Government of Liberia. 2014b. An Act to Amend Certain Provisions of the 1986 Elections Law. Monrovia, Government of Liberia [http://www.necliberia.org/doc_download/New\%20Elections\%20law\%20Amendments.p df].

Government of Liberia. 2016. Affirmative Action for Equitable Participation and Representation Act of 2016. Monrovia: Government of Liberia.

Harris, David. 1999. 'From 'Warlord' to 'Democratic' President: How Charles Taylor Won the 1997 Liberian Elections.” Journal of Modern African Studies 37 (3): 431-455.

Harris, David. 2006. "Liberia 2005: An Unusual African Post-conflict Election.” Journal of Modern African Studies 44 (3): 375-395.

Harris, David and Tereza Lewis. 2012. "Liberia in 2011: Still Ploughing Its Own Democratic Furrow?” Commonwealth \& Comparative Politics 51 (1): 76-96.

The Liberian Connection. n.d. Constitution of the Republic of Liberia (1986). Accessed November 28, 2016 at [http://www.tlcafrica.com/constitution-1986.htm].

Liberia News Agency. 2015. "CRC Delegates Vote on 13 of 25 Propositions So Far." April 2. Accessed November 28, 2016 at [http://www.liberianewsagency.org/pagesnews.php?nid=4448]. 
Liebenow, J. Gus. 1987. Liberia: The Quest for Democracy. Bloomington: University of Indiana Press.

Lyons, Terrence. 1999. Voting for Peace: Postconflict Elections in Liberia. Washington, DC: Brookings Institute.

Manby, Bronwen. 2009. The Struggles for Citizenship in Africa. London and New York: Zed.

National Elections Commission Liberia (NEC Liberia). 2005. Accessed December 11, 2016 at [http://www.necliberia.org/results/].

National Elections Commission Liberia (NEC Liberia). 2011. Accessed December 11, 2016 at [http://www.necliberia.org/results2011/].

National Elections Commission Liberia (NEC Liberia). 2014. Accessed December 11, 2016 at [http://www.necliberia.org/senate2014/].

The New Dawn. 2017. "Winning Ticket?” January 23. Accessed January 25, 2017 at [http://www.thenewdawnliberia.com/news/12588-wining-ticket].

The New Republic. 2016. "Liberia: Rough Road to 2017.” June 20. Accessed February 11, 2017 at [http://allafrica.com/stories/201606201010.html].

The News. 2014. "Ellen Signs CBL Act." March 7. Accessed November 28, 2016 at [http://thenewslib.com/dr-X-says/92-expired-stories/277-ellen-signs-cbl-act] and [http://allafrica.com/stories/201403070945.html].

The News. 2016. “ 'I'll Prove Myself Worthy'.” July 12. Accessed November 28, 2017 at [http://allafrica.com/stories/201607121232.html].

Okuru, Mina and Daniel Armah-Attoh. 2016. "Afrobarometer Dispatch No.121." October 20. Accessed December 11, 2016 at [http://afrobarometer.org/sites/default/files/publications/Dispatches/ab_r6_dispatchno121 _liberia_democracy.pdf].

The Perspective. 2009. "GAC Provides Clarity on Incorrect Salaries Comparison Between AG Morlu, Others.” December 31. Accessed November 28, 2016 at [http://www.theperspective.org/2009/1231200906.html].

Sawyer, Amos. 2005. Beyond Plunder: Toward Democratic Governance in Liberia. Boulder: Lynne Rienner.

Sawyer, Amos. 2008. "Emerging Patterns in Liberia's Post-Conflict Politics: Observations from the 2005 Elections.” African Affairs 107(427): 177-199. 
Sendolo, Joaquin. 2011. "Supreme Court Rules out Residency Clause". African Elections Project, October 7. Accessed December 11, 2017 at

[http://www.africanelections.org/liberia/news/page.php?news=5937].

Sirleaf, Ellen Johnson. 2010. This Child Will Be Great: Memoir of a Remarkable Life by Africa's First Woman President. New York: HarperCollins.

United Nations Security Council (UNSC). 2013. "Security Council Committee on Liberia Delists One Individual from Its Travel Ban and Assets Freeze Lists." December 23. Accessed November 28, 2016 at [http://www.un.org/press/en/2013/sc11229.doc.htm].

United Nations Entity for Gender Equality and the Empowerment of Women (UN Women). 2016. "Signalling a Boost for Gender Equality, Liberia Passes the 'Affirmative Action Bill'." October 3. Accessed November 28, 2016 at [http://www.unwomen.org/en/news/stories/2016/10/liberia-passes-the-affirmative-actionbill].

Voice of America (VoA). 2007. "Liberian Government Takes Exception to Auditor General's Corruption Claims." June 13. Accessed November 28, 2016 at [http://www.voanews.com/a/a-13-2007-06-13-voa5/348280.html].

\footnotetext{
${ }^{\mathrm{i}}$ All actors running in some form in the 2017 elections, at the time of writing, are presented at first in italics.

ii Of the 15 Senatorial elections in 2014, there were just two surviving incumbents, 12 turnovers of political parties, and three independents elected. Note, however, that the turnout was hampered by the Ebola crisis and unusually low at $25.2 \%$, compared to the $71.6 \%$ turnout in 2011 and $74.9 \%$ in 2005 (NEC Liberia 2014; NEC Liberia 2011; NEC Liberia 2005).

iii The controversial model-turned-philanthropist Macdella Cooper of the Union of Liberian Democrats (ULD) is a virtual non-entity in the race because, unlike Jones, Morlu, Urey or Cummings, she lacks sufficient political chutzpah to make a real dent in the election results.
} 